\title{
MAIZE SEED VIGOR AND ITS EFFECTS ON CROP CULTIVATION CYCLE
}

\author{
Vitor Henrique Vaz Mondo ${ }^{1}$, Marcos Altomani Neves Dias ${ }^{2}$, Silvio Moure Cicero $^{2}$ \\ ${ }^{1}$ Embrapa Arroz e Feijão, E-mail: vitor.mondo@embrapa.br \\ ${ }^{2}$ Universidade de São Paulo - ESALQ-USP, E-mail: marcosaltomani@hotmail.com, smcicero@usp.br
}

\begin{abstract}
This study aimed to investigate influences of maize seed vigor on crop cycle. Four maize seed lots with different seed vigor levels were sowed in the field and evaluated daily, computing growing-degree-days for each plot to reach each phenological stage. Differences among treatments during plant development were observed, which occurred at emergence, 4th, 8th, 12th fully expanded leaves and at milk stages. Therefore, it is possible to affirm that seed vigor has impacts on crop cultivation cycle, with plants from lower vigor seeds presenting a delayed development compared to higher vigor seeds. However, such differences tend to disappear during the reproductive phase.
\end{abstract}

Keywords: Phenology, physiological potential, seed quality, Zea mays

\section{VIGOR DE SEMENTES DE MILHO E EFEITOS SOBRE O CICLO DA CULTURA}

\section{RESUMO}

O presente trabalho investigou a influência do vigor de sementes de milho no ciclo da cultura. Quatro lotes de sementes com diferentes níveis de vigor foram semeados e avaliados diariamente no campo, determinando os graus-dias para cada parcela alcançar cada estádio fenológico. Foram observadas diferenças de desenvolvimento das plantas entre os tratamentos, as quais ocorreram nos estádios de emergência, quatro, oito, doze folhas completamente expandidas e grãos leitosos. Assim, pode-se afirmar que o vigor das sementes tem influência no ciclo da cultura, com plantas originadas de sementes de menor vigor apresentando atraso no desenvolvimento comparadas às originadas de sementes de alto vigor. Contudo, estas diferenças tendem a desaparecer durante a fase reprodutiva.

Palavras-chave: Fenologia, potencial fisiológico, qualidade de sementes, Zea mays 


\section{INTRODUCTION}

In a very well written review about the relationship of seed vigor and crop yield, TeKrony \& Egli (1991) described that seed vigor affects vegetative growth and is frequently related to yield in crops harvested at the vegetative stage or during early reproductive growth, and usually has no relationship with crops harvested at full reproductive maturity. The authors concluded that it occurs because grain yields are usually not closely related to vegetative growth. In accordance, Mondo et al. (2012b) showed in maize populations that seed vigor affects plant growth until harvest, which was observed by plant dry mass accumulation, even though it did not affect plant individual grain yield. However, according to Hampton (2002), seed vigor has a high influence on establishment of initial population of plants as well as on their adequate development, that will affect crop yield. In addition, TeKrony \& Egli (1991) concluded that seed vigor may play an important role in terms of crop yield, in situations where the vegetative growth is closely related to it (i.e., low population densities, late plantings). The results compiled by TeKrony \& Egli (1991) indicated that the effect of seed vigor, when using proper plant densities, can be seen in the plants at early stages of development, in a several number of species. Marcos-Filho (2005) affirmed that seed vigor can affect the crop early growth; however, this effect has a tendency to disappear until the end of crop cycle. Marcos-Filho \& Kikuti (2006) also observed that high seed vigor on radish crop could boost plant early development, but the effect did not persist until harvest.

Similar results are found in more recent studies involving seed vigor and crop performance. Vanzolini \& Carvalho (2002) and Schuch et al. (2009) with soybeans, Mondo et al. (2012b; 2013a; 2013b) and Dias et al. (2010) with maize, showed the effect of seed vigor being expressed mainly along plant vegetative stages. However, Scheeren et al., (2010) observed that the yield of plots sowed with high vigor seed lots were up to $9 \%$ higher than plots sowed with low vigor seeds. Panozzo et al., (2009) found similar results for soybean, showing that seed vigor influences directly the individual plant performance, which increases potential yield in $17 \%$.

However, a limited number of works in literature have discussed whether the inferior development of plants, normally given by plant growth parameters (i.e, plant height, leaf area index and dry mass accumulation), is mainly related to a lower 
development rate or to a delayed emergence, which also can have an effect regarding crop phenology.

Phenology is the study of development, which refers to ontogenetic processes at different levels of organization that a crop goes through during its life cycle, and extends from cell differentiation, organ initiation (organogenesis) and appearance (morphogenesis), to crop senescence (WILHELM \& MCMASTER, 1995). It is clear that characterizing and understanding crop phenology is crucial for field crop management practices such as fertilization, pest control and irrigation scheduling (STRECK et al., 2008). For maize crop, temperature is one of the major environmental factors regarding to growth, development and yield, especially the development rate. Basically, a maize plant has a minimum temperature requirement to complete a specific phenological phase. Thus, plants developed from late emerged seedlings should present longer cycles than the ones developed from early emerged seedlings.

Since 1730, when Reaumur introduced the concept of heat units or thermal time, many methods of calculating heat units have been used successfully in agricultural sciences (MCMASTER \&
WILHELM, 1997). Particularly in the areas of crop phenology and development, the concept of heat units, measured in growing degree-days (GDD), has vastly improved description and prediction of phenological events compared to other approaches such as time of year or number of days (CROSS \& ZUBER, 1972), and is a recommended tool for evaluating the cultivation cycle.

Therefore, this study aimed to investigate the influence of maize seed vigor on crop cycle.

\section{MATERIAL AND METHODS}

The experiment was carried out during 2007/2008 growing season in Piracicaba, SP, Brazil (22\%42'30”S, $47^{\circ} 38^{\prime} 00^{\prime \prime} \mathrm{N}, 546 \mathrm{~m}$ above sea level). The soil, a Rhodic Kandiudalf containing 24 g. $\mathrm{dm}^{-3}$ of organic matter and $\mathrm{pH} 4.9$, was conventionally prepared for the experiment. The previous crop in the area was soybean. A maize hybrid (DOW 8480) was sowed in plots on January $15^{\text {th }}, 2008$. Each plot was composed of three $11 \mathrm{~m}$ rows, spaced at 0.7 $\mathrm{m}$, with an evaluation area corresponding to $10 \mathrm{~m}$ of the middle row. The seeds were hand-sown and, at 2-leaves-stage, a thinning was proceeded in order to obtain a total population of 71,429 plants.ha ${ }^{-1}$. Nitrogen, 
phosphorus and potassium were applied before sowing at the rates of 32, 112 and 64 $\mathrm{kgha}^{-1}$, respectively. The plots received 90 $\mathrm{kgha}^{-1}$ of $\mathrm{N}$ at five-leaves-stage, and were kept free of weeds, pests and diseases throughout the crop cycle. The experiment was irrigated only in order to allow proper seedlings emergence, providing the desired plant stand. Total rainfall and average temperature along the experiment were 865 $\mathrm{mm}$ and $22.3^{\circ} \mathrm{C}$, respectively.

The treatments consisted of four seed lots composed by same size seeds, but different on vigor level. The plant material was offered by Dow Agro Sciences, located in Cravinhos, SP, Brazil, being two of them, produced in the $2005 / 2006$ and the other two in the $2006 / 2007$ summer seasons. The seed lots were kept on controlled conditions of temperature $\left(20^{\circ} \mathrm{C}\right)$ and relative humidity (40\%) from processing to planting.

\section{Seed lot characterization}

Seed Moisture Content (MC) was determined by oven drying two samples of each seed lot for $24 \mathrm{~h}$ at $105 \pm 3{ }^{\circ} \mathrm{C}$. Afterwards, the samples were placed in a desiccator at room temperature for 20 minutes, followed by weighing (BRASIL, 2009).
Germination $(\mathrm{G})$ was carried out with four replicates of 50 seeds per lot, in rolls containing three sheets of paper towel, moistened with water at 2.5 times the weight of the dry paper. The rolls were placed in a dark germination chamber at $25{ }^{\circ} \mathrm{C}$. The number of normal seedlings was recorded on the $4^{\text {th }}$ and $7^{\text {th }}$ day after sowing (BRASIL, 2009).

Seedling emergence (SE) was carried out in the field, with eight replicates of 50 seeds per lot. Seeds were uniformly distributed at a depth of $3 \mathrm{~cm}$, in $2.5 \mathrm{~m}$ long rows, spaced at $0.5 \mathrm{~m}$. The soil was watered to provide sufficient moisture for seedling emergence. The emerged seedlings (with coleoptiles at least $1 \mathrm{~cm}$ above the soil surface) were daily counted in order to calculate the seedling emergence speed index (SESI) (MAGUIRE, 1962). At the $14^{\text {th }}$ day after sowing, the final count was preceded, computing the total emerged seedlings.

Accelerated aging (AA) was performed with four replicates of 50 seeds per lot. The seeds were placed upon a screen inside a transparent plastic box $(11 \mathrm{x} 11$ $\mathrm{x} 3 \mathrm{~cm}$ ) and suspended over $40 \mathrm{~mL}$ of water. The AA boxes were placed in a germination chamber maintained at $41 \pm 1{ }^{\circ} \mathrm{C}$ for $96 \mathrm{~h}$. After the aging period, seeds were submitted 
to germination test, as described previously, and the normal seedlings were counted at the $4^{\text {th }}$ day after sowing.

Cold test (CT) was carried out with four replications of 50 seeds per lot, uniformly distributed in plastic trays (34 $\mathrm{x}$ $23 \times 7 \mathrm{~cm})$,filled with a soil-sand substrate $(25-75 \%)$ moistened at $60 \%$ of water holding capacity. After sowing, the trays were maintained in a chamber at $10^{\circ} \mathrm{C}$ for 7 days, and then placed in a germination chamber at $25^{\circ} \mathrm{C}$. On the $5^{\text {th }}$ day, the number of emerged seedlings with coleoptiles at least $1 \mathrm{~cm}$ above substrate surface was recorded.

\section{Cultivation cycle evaluation}

The plots were daily evaluated, computing the moment that at least $50 \%$ of the plants on the plot evaluation area had reached the phenological stage. Afterwards, based on the concept of heat units, the growing degree-days were calculated using equation 1.

$$
\text { GDD }=\left[\frac{(\operatorname{Tmax}+\mathrm{Tmin})}{2}\right]-\text { Tbase }
$$

Equation 1. Growing degree-days. Tmax is the maximum daily air temperature, Tmin is the minimum daily air temperature and Tbase is the temperature below which the process of interest does not progress.

\section{Statistical analysis}

Seed lot characterization was conducted in a completely randomized design and the field experiment in a randomized block design, both with four replications. Data was analyzed by ANOVA ( $F$ test) and, in case of significance, means were compared by Tukey test (5\%).

\section{RESULTS AND DISCUSSION}

The results from seed lot characterization obtained by physiological tests were recorded (Table 1). All seed lots had similar germination results, varying from $95 \%$ to $99 \%$, pointing for a high quality in terms of seed viability for all lots, whilst also showing similarity in terms of seed moisture content. However, it was possible to observe variations on seed quality when vigor tests were conducted. Lots one and four had different performances for all vigor tests used in this study (SE, SESI, AA and CT) and were classified as the highest and the lowest vigor lots, respectively. Lots two and three were similar in all tests, being superior to lot four for all vigor tests and inferior to lot one for $\mathrm{AA}$ and $\mathrm{CT}$ evaluations. Based on those results, they were classified as intermediate vigor lots. 
The development cycle of maize is divided into two major phases: vegetative, that comprehends from $\mathrm{E}$ to silking (R1), and reproductive, from R1 to physiological maturity (R6) (Ritchie et al., 1997). effects of seed vigor on maize vegetative phase became clear, at least on crop cultivation cycle.

The ANOVA data for crop phonological stages is presented (Table 2).

Considering these phenological stages, the

Table 1. Maize seed lot characterization. Moisture content (MC; \%), Germination (G; \%), Seedling emergence (SE; \%), Seedling emergence speed index (SESI), Accelerated aging (AA; \%) and Cold test (CT; \%).

\begin{tabular}{cccccccc}
\hline Lot & MC & G & SE & SESI & AA & CT & $\begin{array}{c}\text { Seed vigor } \\
\text { classification }\end{array}$ \\
\hline 1 & 8.6 & $99 \mathrm{a}^{*}$ & $98 \mathrm{a}$ & $16.0 \mathrm{a}$ & $91 \mathrm{a}$ & $97 \mathrm{a}$ & High \\
2 & 8.7 & $96 \mathrm{a}$ & $93 \mathrm{a}$ & $14.7 \mathrm{a}$ & $63 \mathrm{~b}$ & $46 \mathrm{~b}$ & Intermediate \\
3 & 9.3 & $98 \mathrm{a}$ & $96 \mathrm{a}$ & $14.8 \mathrm{a}$ & $75 \mathrm{~b}$ & $46 \mathrm{~b}$ & Intermediate \\
4 & 9.7 & $95 \mathrm{a}$ & $67 \mathrm{~b}$ & $9.0 \mathrm{~b}$ & $5 \mathrm{c}$ & $2 \mathrm{c}$ & Low \\
\hline $\mathrm{CV}$ & & 5.6 & 6.6 & 6.8 & 16.7 & 14.3 & \\
\hline
\end{tabular}

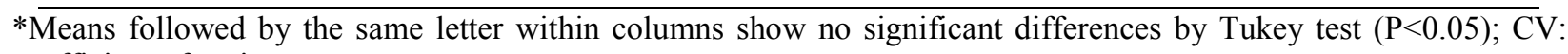
coefficient of variance.

Table 2. Analysis of variance for seed vigor influence on maize phenological stages.

\begin{tabular}{|c|c|c|c|c|}
\hline \multirow[b]{2}{*}{ Development stage } & \multicolumn{4}{|c|}{ Seed Vigor } \\
\hline & $\begin{array}{l}\text { High } \\
\text { (Lot 1) }\end{array}$ & $\begin{array}{c}\text { Intermediate } \\
\text { (Lot 2) }\end{array}$ & $\begin{array}{l}\text { Intermediate } \\
\text { (Lot 3) }\end{array}$ & $\begin{array}{c}\text { Low } \\
\text { (Lot 4) }\end{array}$ \\
\hline (E) Emergence & $89 *$ & 100 & 100 & 103 \\
\hline $4^{\text {th }}$ fully expanded leaf (V4) & $326^{* *}$ & 334 & 372 & 389 \\
\hline $8^{\text {th }}$ fully expanded leaf (V8) & $580^{*}$ & 580 & 613 & 620 \\
\hline $\begin{array}{l}12^{\text {th }} \text { fully expanded leaf } \\
\text { (V12) }\end{array}$ & $738^{* *}$ & 745 & 775 & 782 \\
\hline Tasseling (T) & $899^{\text {ns }}$ & 912 & 928 & 923 \\
\hline Silk (R1) & $965^{\text {ns }}$ & 972 & 979 & 979 \\
\hline Blister (R2) & $1089 * *$ & 1089 & 1103 & 1110 \\
\hline Milk (R3) & $1245^{\mathrm{ns}}$ & 1245 & 1248 & 1248 \\
\hline Dough (R4) & $1383^{\mathrm{ns}}$ & 1383 & 1392 & 1389 \\
\hline Dent (R5) & $1567^{\mathrm{ns}}$ & 1567 & 1567 & 1567 \\
\hline Physiological maturity (R6) & $1689^{\text {ns }}$ & 1689 & 1689 & 1689 \\
\hline
\end{tabular}


Differences among treatments were observed only on phenological stages of emergence (E), $4^{\text {th }}$ fully expanded leaf (V4), $8^{\text {th }}$ fully expanded leaf (V8), $12^{\text {th }}$ fully expanded leaf (V12) and at milk stage (R2). It was possible to verify that seed vigor influenced the first stages of plants development, at least until V12.

In a more detailed analysis (Figure 1), the Tukey test allowed to visualize differences among seed lot performance in the field for each phenological stage. Clearly, it was possible to identify the difference on crop development between lot one and four, with lot four demanding more growing-degree-days (GDD) than lot one to reach the same phenological stage. Lots two and three continued with an intermediate performance, sometimes closer to lot one, sometimes closer to lot four. Vanzolini \& Carvalho (2002), working with seed vigor and crop performance for soybean, identified that seed lots with lowest vigor resulted in the elongation of crop vegetative phase. It agrees with the results found in the present work, where the seed vigor inferiority had influenced on crop cultivation cycle, and it occurred mainly in the vegetative phenological stages.

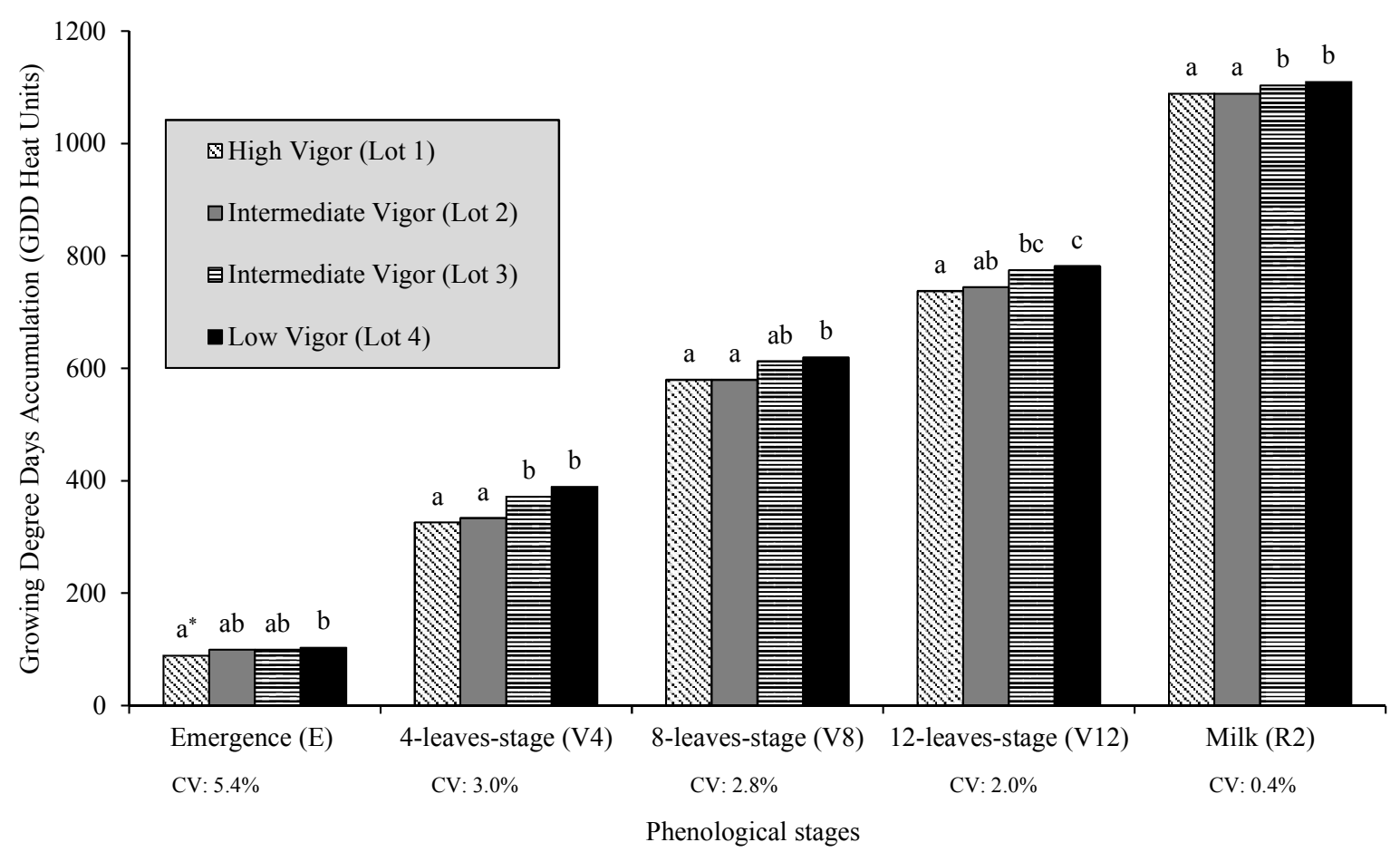

*Means followed by the same letter within each phenological stage show no significant differences by Tukey test $(\mathrm{P}<0.05)$; CV: coefficient of variance.

Figure 1. Growing-degree-days to reach phenological stages of development on maize. 
Analyzing the phenological stages affected by seed vigor, it was possible to observe that crop cultivation cycle was influenced from $\mathrm{E}$ to V12. After that, at Tasseling (T) and R1 phases, no significant differences among treatments were observed. Those results were expected and agreed with the results found by Mondo et al. (2012b), who concluded that seed vigor was directly related to maize plants initial growth, but those effects did not persist until harvest. In addition, the same authors concluded that heterogeneities in terms of seed vigor within a seed lot could result in an increase of intra-specific competition, which can affect crop performance in later phenological stages. Considering this, it is feasible to affirm that variation on plants development rate and the unevenness of seedling emergence intensified intraspecific competition, explaining the differences found at R2, which was the only reproductive phenological stage affected.

The effect of seed vigor on total crop cultivation cycle was recorded (Figure 2). It illustrates the phases really affected by the seed quality and which phenological stages the differences have shown up. The impact of seed vigor can be observed on $\mathrm{E}$ to $\mathrm{T}$, or, during the vegetative phase, whilst it tends to disappear during reproductive phase. Finch-
Savage (1995) also studied the effect of seed vigor on plant development, and those originated from low vigor seeds were in a delayed phenological stage compared to the ones originated from high vigor seeds.

An important point to be questioned is the real impacts of seed vigor in the crop management. Considering that the most effective method for controlling weeds in the field is the crop ability to compete against them, the use of low vigor seeds may reduce this skill, which negatively impacts the integrated weed management systems. Dias et al. (2010; 2011) and Mondo et al. (2012a) also mentioned the important role of using vigorous seed lots as a manner to obtain a fast growth and development of plants, and also a higher competitive ability against weeds in the field.

Also in regard to agriculture sustainability, the impacts of prolonging crop development could affect the efficiency of nutrient uptake and water demand, considering that the plants could be in different stages of development and have different demands for nutrients. Also, the water necessity can be extended for a longer period, based on the elongation of phenological stages to reach the reproductive phase. 


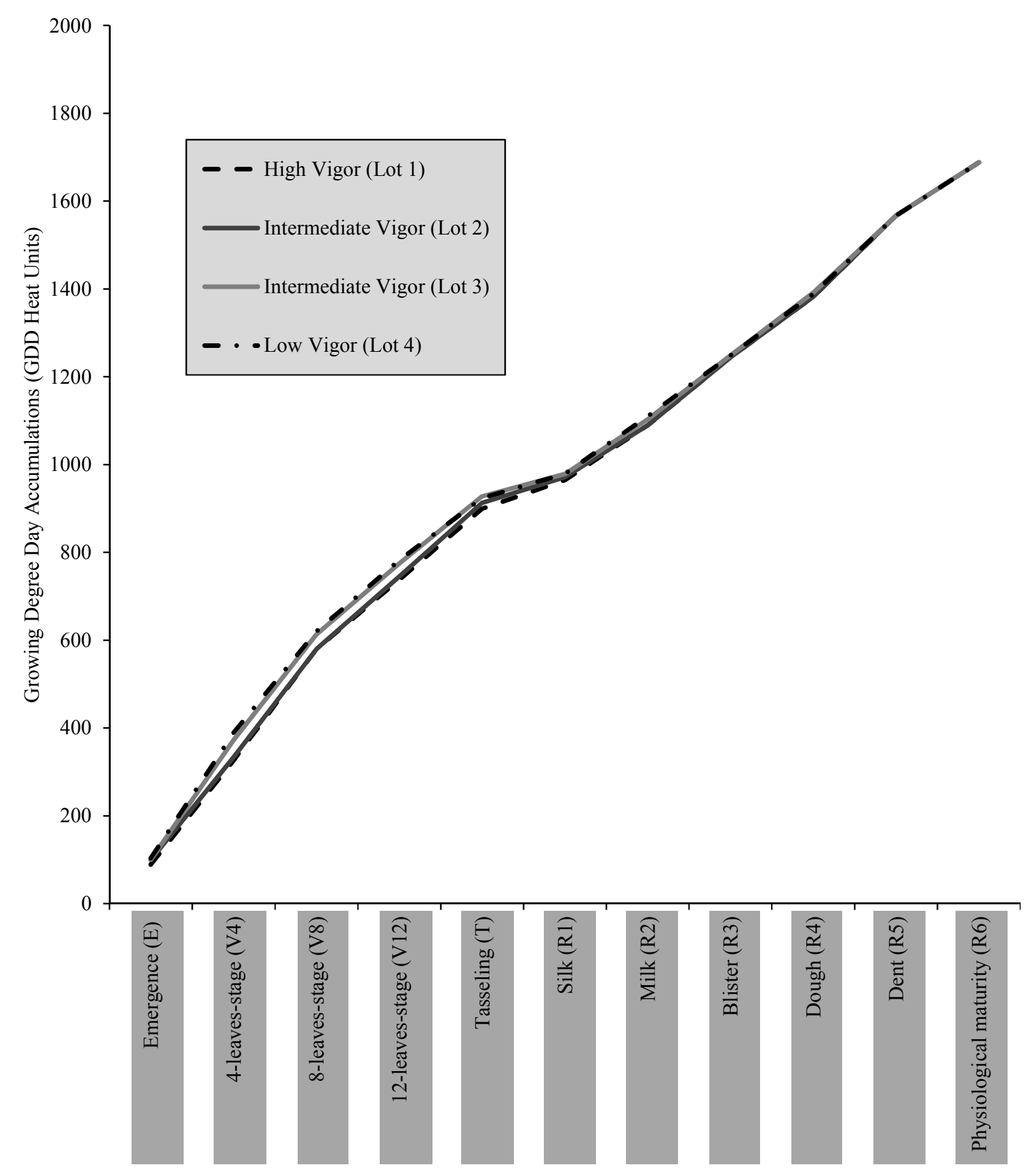

Figure 2.Growing-degree-days to reach phenological stages of development on maize during crop cultivation cycle.

\section{CONCLUSIONS}

Seed vigor has impacts on maize crop cycle, where low vigor seeds have delayed crop development during the vegetative phase, when compared to high vigor seeds. However, those differences tend to disappear during the reproductive phase. 


\section{REFERENCES}

BRASIL. Ministério da Agricultura, Pecuária e Abastecimento. 2009. Regras para análise de sementes. Brasília: MAPA/ACS, 399p.

CROSS, H.Z.; ZUBER, M.S. 1972. Prediction of flowering dates in maize based on different methods of estimating thermal units. Agronomy Journal, Madison, v.64, n.3, p.351-355.

DIAS, M.A.N.; MONDO, V.H.V.; CICERO, S.M. 2010. Maize seed and weed competition. Journal of Seed Science, Londrina, v.32,n.2, p.93-101.

DIAS, M.A.N.; PINTO, T.L.F.; MONDO, V.H.V.; CICERO, S.M.; PEDRINI, L.G. 2011. Direct effects of soybean seed vigor on weed competition. Journal of Seed Science, Londrina, v.33, n.2, p.346-351.

FINCH-SAVAGE, E.W. 1995. Influence of seed quality on crop establishment, growth, and yield, "Seed quality: basic mechanisms and agricultural implications", pp.362-384. Basra AS, ed. Food Products Press, New York.

HAMPTON, J.G. 2002. What is seed quality? Seed Science and Technology, Bassersdorf, v.30, n.1,1-10.

MARCOS-FILHO, J. 2005. Fisiologia de sementes de plantas cultivadas. Piracicaba: Fealq. 495p.

MARCOS-FILHO, J.; KIKUTI, A.L.P. 2006. Radish seed vigor and plant field performance. Journal of Seed Science, Pelotas, v.28, n.3, p.44-51.

MAGUIRE, J. 1962. Speed of germination aid in selection and evaluation for seedling emergence and vigor. Crop Science, Madison, v.2, n.2, p.176-77.

MCMASTER, G.S.; WILHELM, W.W. 1997. Growing degree-days: one equation, two interpretations. Agricultural and Forest Meteorology, Lincoln, v.87, n.4, p.291-300.
MONDO, V.H.V.; CICERO, S.M.; DIAS, M.A.N.2012a. Vigor de sementes e a mato competição. Informativo Abrates, Londrina, v.22, n.1, p.30-34.

MONDO, V.H.V.; CICERO, S.M.; DOURADO-NETO, D.; PUPIM, T.L.; DIAS, M.A.N .2012b. Maize seed vigor and plant performance. Journal of Seed Science, Londrina, v.34, n.1, p.143-155.

MONDO, V.H.V.; CICERO, S.M.; DOURADO-NETO, D.; PUPIM, T.L.; DIAS, M.A.N. 2013a. Effect of seed vigor on intraspecific competition and grain yield in maize. Agronomy Journal, Londrina, v.105, n.1, p.222228.

MONDO, V.H.V; CICERO, S.M.; DOURADO-NETO, D.; PUPIM, T.L.; DIAS, M.A.N. 2013b. Seed vigor and initial growth of corn crop. Journal of Seed Science, Londrina, v.35, n.1, p.6469.

PANOZZO, L.E.; SCHUCH, L.O.B.; PESKE, S.T.; MIELEZRSKI, F.; PESKE, F.B. 2009. Behavior of plants originated from soybean seeds with different levels of physiological quality. Revista da FZVA, Uruguaiana, v.16, n.1, p.32-41.

RITCHIE, S.W.; HANAWAY, J.J.; BENSON, G.O. 1986. How a corn plant develops. Specialty Report 48. Iowa State Extension Service, Iowa State University, Ames.

SCHEEREN, B.R.; PESKE, S.T.; SCHUCH, L.O.B.; BARROS, A.C.A. 2010. Physiological quality of soybean seeds and productivity. Journal of Seed Science, Londrina, v.32, n.3, p.35-41.

SCHUCH, L.O.B., KOLCHINSK, E.M., FINATTO, J.A. 2009. Seed physiological quality and individual plants performance in soybean. Journal of Seed Science, Londrina, v.31, n.1, p.144-149.

STRECK, N.A.; LAGO, I.; GABRIEL, L.F.; SAMBORANHA, F.K. 2008. Simulating 
maize phenology as a function of air temperature with a linear and a nonlinear model.Pesquisa

Agropecuária Brasileira, Brasília, v.43, n.4, p.449455.

TEKRONY, D.M.; EGLI, D.B. 1991.Relationship of seed vigor to crop yield: a review. Crop Science, Madison, v.31, n.3, p.816-822.

VANZOLINI, S.; CARVALHO, N.M. 2002. Effects of soybean seed vigor on field plant performance. Journal of Seed Science, Londrina, v.24, n.3, p.33-41.

WILHELM, W.W.; MCMASTER, G.S. 1995. The importance of thephyllochron in studying the development of grasses. Crop Science, Madison, v.35, n.1, p.1-3.

Recebido em: 18/8/2014 Aceito para publicação em:15/9/2015 